\title{
Perceptions and use of medicinal plants by an elementary and high school community in Vila Velha, Espírito Santo, Brazil
}

\author{
Wilka Messner da Silva Bispo', Edilene Ferreira Freitas', \\ Ariane Pinheiro Cruz ${ }^{2}$, Racire Sampaio Silva ${ }^{2}$, Marcio Fronza ${ }^{\circledR 2 *}$ \\ ${ }^{1}$ Curso de Farmácia, Universidade Vila Velha, Vila Velha, Espírito Santo, Brasil, \\ ${ }^{2}$ Programa de Pós-Graduação em Ciências Farmacêuticas, Laboratório de Produtos \\ Naturais, Universidade Vila Velha, Vila Velha, Espirito Santo, Brasil
}

\begin{abstract}
Plants have been used for centuries as therapeutic resources for various pathological conditions and are occasionally considered as the only resource available to some communities. However, knowledge on the potential of traditional medicinal plants have been lost over the years. Strategies that can guarantee the prospection of popular knowledge regarding medicinal plants to stimulate the spread of information between generations are therefore of enormous value. Thus, the present study aimed to investigate the use and knowledge on medicinal plants of students from a public school in Vila Velha (Brazil) and their associated community, including parents. In this urban locality, data were obtained by the application of a semi-structured questionnaire to 206 people from the school community. Although homegrown cultivation seems to be an uncommon practice in urban contexts, the use of medicinal plants by the sampled population was significant (80\%), as well as the interviewees' confidence on its therapeutic action (90\%). It is worth mentioning that more than $70 \%$ of the respondents presented their parents and/or grandparents as their main source of information, highlighting the importance of popular knowledge valorization.
\end{abstract}

Keywords: Medicinal plants, Phytotherapy. Popular medicine. Traditional medicine.

\section{INTRODUCTION}

Throughout history, humanity has always tried to develop strategies in properly managing and using natural resources to meet its daily needs. This is especially true regarding the use of plant resources, which are present in many aspects of people's lives in varied cultures around the world (Albuquerque et al., 2005).

The use of plants for health recovery is a common practice and is often considered as a product of secular accumulation of popular knowledge (Samuelsson, Bohlin, 2017). Even with advancements in medicine, for a large part of the population, the use of traditional medicinal plants still constitutes the main alternative for treating several pathologies. In fact, for some communities, traditional

*Correspondence: M. Fronza. Departamento de Farmácia. Universidade Vila Velha - UVV. Av. Comissário José Dantas de Melo, n. 21, Boa Vista. Vila Velha, ES, 29102-920, Brazil. Phone: +55 (27) 3421-2001. E-mail: marcio.fronza@uvv.br medicinal plants are the only existing therapeutic resource not only due to their proven therapeutic efficacy, but also due to their lower associated costs along with the dissatisfaction of the general population with the official health system (Cappelleti Nagai et al., 2010). According to data from the World Health Organization (WHO), 80\% of the world's population uses traditional practices in primary care, and $85 \%$ uses medicinal plants or derivatives in the struggle against harmful physiological alterations (Freire et al., 2018).

Although the increased availability of synthetic substances with pharmacological properties resulted in a reduction in the use of these natural resources, a new frenzy about these products was observed in the 1960s and the demand for phytotherapy and natural therapies has gradually increased since then (Harvey et al., 2005), especially when combined with conventional therapy (Eisenberg et al., 1993). Considering medicinal plants as second-class drugs have returned to the vogue with 
evidence of relevant pharmacological actions and an excellent cost-benefit relationship (Almeida, 1993). In this sense, the study of popular knowledge on alternative therapies of a certain ethnic or social group has gained importance in the development of new medicines based on the potential of medicinal plants (Rodrigues, Carlini, 2005). Plants are considered a fruitful source of bioactive chemicals such as atropin, ephedrine, morphine, caffeine, salicylic acid, digoxin, taxol, galantamine, vincristine and colchicines; and approximately $25 \%$ of the prescription drugs dispensed in the United States contain at least one active ingredient of plant origin (Orhan, 2014). Therefore, the knowledge of natural products or their derivative compounds offer valuable advancements for drug discovery, demonstrating that the current importance of drugs of natural origin is undebatable (Orhan, 2014).

As aforementioned, the knowledge on the use of medicinal plants is widespread but if it is not scientifically investigated nor properly recorded, most of it will be lost with succeeding generations due to inadequate documentation and limited intergenerational transfer of knowledge (Maroyi, 2011). Therefore, strategies that guarantee the prospection of popular knowledge and stimulate the dissemination of this information to the following generations are of enormous value.

Knowledge about the curative power of plants should not only be considered as a tradition handed down from parents to children, but as a science that has been studied, perfected and applied by different cultures throughout the ages (Heisler et al., 2012). Thus, studies that aim to investigate strategies and teaching methodologies for reinforcing traditional knowledge are fundamental to encourage educational programs to emphasize the importance of plant resources for medicine development to children and juveniles. Through a process of dialogue with scientific knowledge, such studies can guarantee the transmission of information to a community and stimulate a persistent concern about the effects of natural resources on health (Cappelleti Nagai et al., 2010).

One of the ways to construct the comprehension of new ideas and reinforce as well as form social interests and experiences stems from the teaching-learning process that takes place in classrooms (Santomé, 1995). In addition to the provision of scientific knowledge, it is also important to value and express popular knowledge within school integration that students bring from outside experiences, ultimately fostering the construction of a socialized and meaningful knowledge (Kovalski, Obara, 2013). Indeed, through activities building and expanding upon different cultures and identities, the promotion, protection, recovery and rehabilitation of health are achieved (Cappelleti Nagai et al.,2010).

It is noteworthy that the use of medicinal plants is not restricted to rural areas (Nair, 2004), arising valuation of this transmitted knowledge to an urban environment. While there is cultural richness present in the subject, few studies seek to understand the relevance of the subject in an urban environment and only a few ethnobotanical studies for urban backyards are available. (Fuck et al., 2005; Lima et al., 2007; Siviero et al., 2012; Messias et al., 2015). Regarding the above, the present study aimed to investigate the ethnobotanical knowledge of students from an urban locality, along with their associated community, on medicinal plants.

\section{MATERIAL AND METHODS}

\section{Study area and target audience}

The study was conducted during 2016-2017 in the state elementary and high school community of 'Agenor de Souza Lé', Vila Velha city, Espírito Santo state $\left(20^{\circ}\right.$ 19' 48' S 40 17'3” W) (Figure 1). All participants, students and parents, were at least twelve years old or older in order to achieve full comprehension of the questionnaire and trustworthiness in their responses. In total, 206 participants were randomly selected and personally interviewed. To perform this research, the project was evaluated by the Research Ethics Committee (CEP) of the Vila Velha University, being duly approved by technical advice number 1593828 in accordance with the criteria established by the Code of Ethics in Research (CNS Resolution 196/96). 


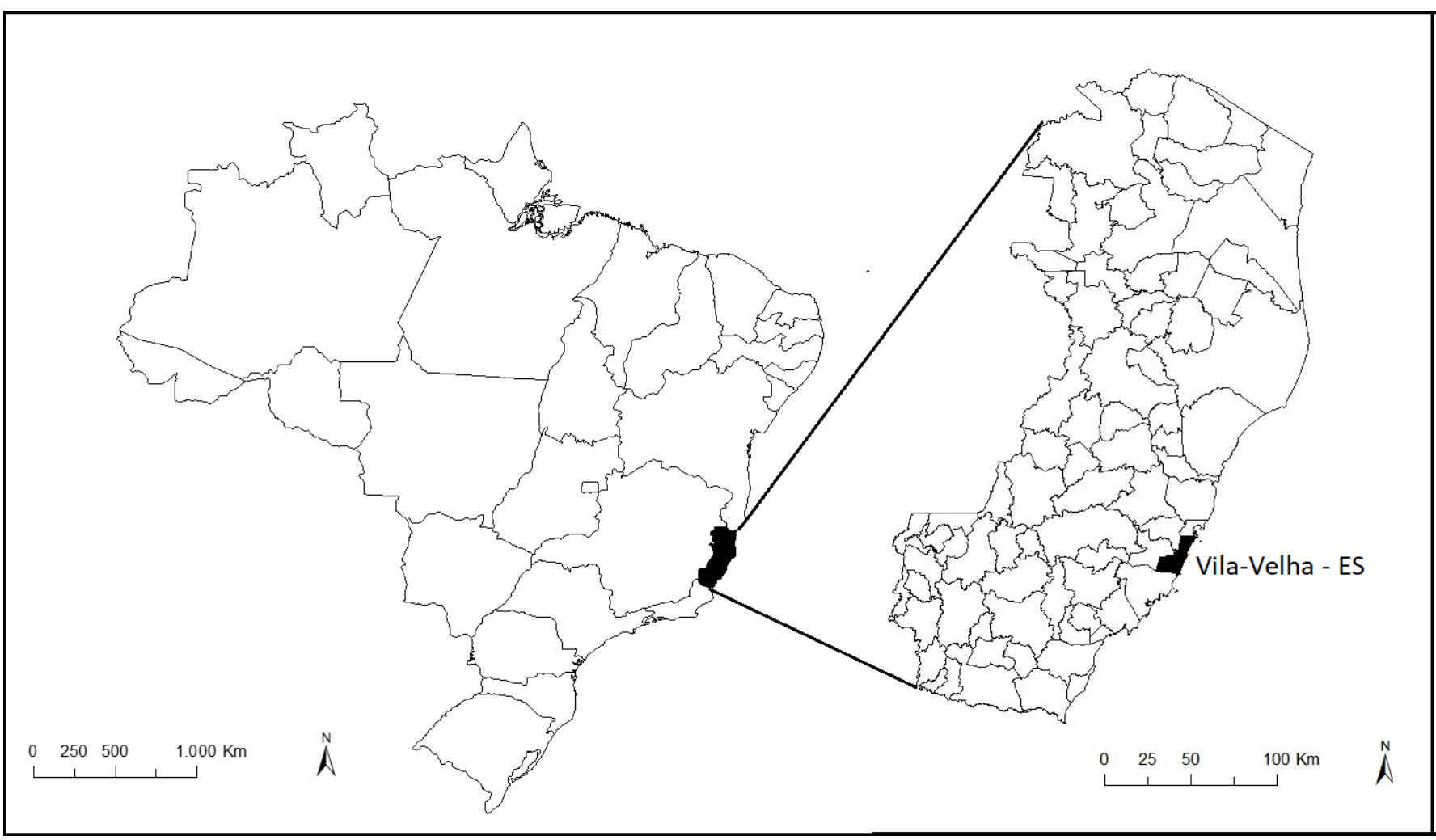

FIGURE 1 - Map of Brazil with emphasis on the Espirito Santo state and VilaVelha city, where the study was conducted. This map was drawn from the cartographic base of IBGE (Instituto Brasileiro de Geografia e Estatística) available in https:/mapas. ibge.gov.br/.

\section{Data collection and analysis}

Data collection was carried out through a semistructured questionnaire containing open and closed questions (Albuquerque et al., 2008). The addressed questions were related to interviewees' personal data (name, age, gender, schooling and aspects of their family environment) as well as to their basic knowledge on medicinal plants (purpose of use, mode of collection, used parts and preparation forms). Prior to the questionnaire application, the Informed Consent Form was presented to the interviewees and signed, authorizing the research procedure. As recommended by Phillip and Gentry (1993), all respondents were individually interviewed in order to avoid the influence of another participant. At the end of the study, the plants mentioned in the interviews were identified and added to a medicinal garden at the school. The corrected names of the species and botanical families were confirmed using The Plant List (2013) database at http://www.theplantlist.org/.

Data analysis was performed quantitatively in terms of relative frequencies (RF) according to the equation
$\mathrm{RF}=\mathrm{R} / N_{t}$ or $N_{m}$ or $N_{f}$, where R represents the number of responses to the addressed question; $N_{t}$ represents the total number of interviewees, $N_{m}$ represents the total number of male interviewees; and $N_{f}$ represents the total number of female interviewees (Madikizela et al.,2012; Napagoda et al., 2018). To identify the significance in the prevalence of positive responses to the questions related to knowledge and use of medicinal plants between female and male respondents, the prevalence ratio (PR) was used (Jolly et al., 2010), according to the equation: $\mathrm{PR}=(a / a+b) /(c /$ $c+d$ ), where $a$ represents the positive responses of female respondents; $b$ represents the negative responses of female respondents; $c$ represents the positive responses of male respondents; and $d$ represents the negative responses of male respondents.

\section{RESULTS AND DISCUSSION}

The state of Espírito Santo represents one of the endemic centers in the Atlantic Domain; however, its biodiversity has been threatened every day by anthropic activities (Murray-Smith et al., 2008). Due to real 
estate speculation, sand removal from resting regions, disorderly withdrawal of animal and plant specimens, and direct or indirect pollution from the accumulation of garbage and sewage, many plant species are eliminated before being studied for ecological characteristics, therapeutic or ornamental potential, food or any other benefits they may bring to the community (Albertasse et al., 2010).

Vila Velha is the oldest and most populous city of Espírito Santo; presently consolidated as an environmentally fragile territory where urban structures have destroyed most of its natural elements, promoting changes in the natural landscape due to a newly altered landscape (Siqueira, 2001). Thus, ethnobotanical studies in this area are justified regarding the dynamic character of popular medicine and the risk of disappearing plant species and cultural practices of the populations occupying the areas off the coast of Espírito Santo, as previously observed by Albertasse et al. (2010).

With respect to the sociodemographic data collected in this research from 206 interviewees (58.73\% female and $41.46 \%$ male), $70.87 \%$ were framed in the age group of 12 to 20 years, $23.30 \%$ in the age group of 21 to 45 years and only $5.83 \%$ were older than 45 years. These results indicated that most of the interviewees are students of school age and about $70 \%$ are attending elementary or high school education. Regardless of the age group, $60.68 \%$ of the interviewees comprised residents of the municipality of Vila Velha, especially in neighborhoods adjacent to the school. Only $19 \%$ from the total number of interviewees lived in neighborhoods considered noble by the city's population, while $81 \%$ of interviewees were residents from outlying districts. Regarding the number of residents reported for each household, it was observed that $50.49 \%$ of the interviewed people shared a dwelling with three other people, totaling to four residents per household. Respondents living in households that sheltered more than six people accounted for $11.65 \%$ of the total interviewees, while those sheltered in homes shared by only two people accounted for $13.59 \%$.
As shown in TABLE I, although a considerable fraction of users did not cultivate any medicinal plants at home, the majority of respondents believed in their therapeutic efficacy and reported minimal use of some sort of plant species for this purpose. Nearly over $70 \%$ of the respondents referred to infusion as the most commonly used method for the preparation of medicinal products (Figure 2) and about 90\% referred to leaves as the most used plant part (Figure 3). The use of leaf infusion is often observed in studies conducted for this purpose, such as David et al. (2014). As expected, the results showed that medicinal plant users do not always contemplate the part and amount of the plant utilized for the preparations, or the harvesting procedure. It is important and necessary to observe that the population was sometimes unaware of the possible toxicity or adverse effects of plants and of their proper use and indications (Ibiapina et al., 2014), as can be seem in TABLES I and II.

According to Pires et al. (2016), the subject of medicinal plants is poorly discussed in Brazil, especially in urban areas, even though the use of medicinal preparations by the population is observed. Nonetheless, it is still noted that the focal point for a myriad of therapies is on biomedical technologies based on a single purified active principle and its mechanism of action. Thus, to many people, the use of medicinal plants seems as a remnant of underdeveloped times and the interest in medicinal plants as a health aid has decreased over the years. This distorted view leads to the irrational use of these plants, neglecting procedures and cautions that may be essential for the proper functioning and safety of their associated therapies. As also emphasized by Pires et al. (2016), this reality evidences that the use of medicinal plants has been carried out solely based on home experiences and popular knowledge, even when a community does not have full knowledge about its use and/or scientific proof. The indiscriminate practice of using medicinal plants can cause ineffective treatment and even put those who practice it at risk, given that each medicinal species has specificities in regard to manipulation, cultivation and forms of administration. 


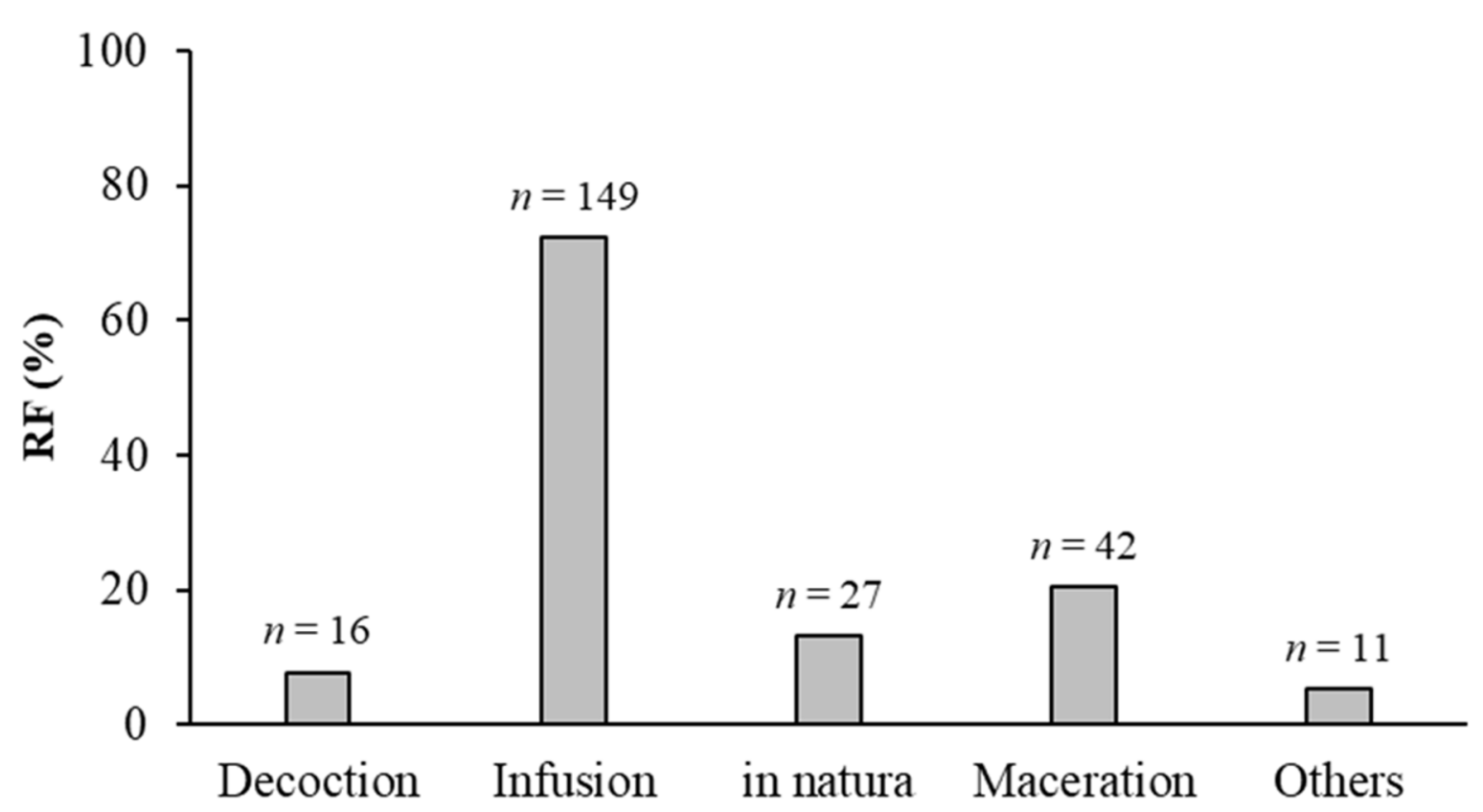

\section{Preparation method}

FIGURE 2 - Main methods of herbal preparations cited by the students and their associated community at a public school in Vila Velha (Brazil). $n$ represents the number of answers for each category considering 206 people.

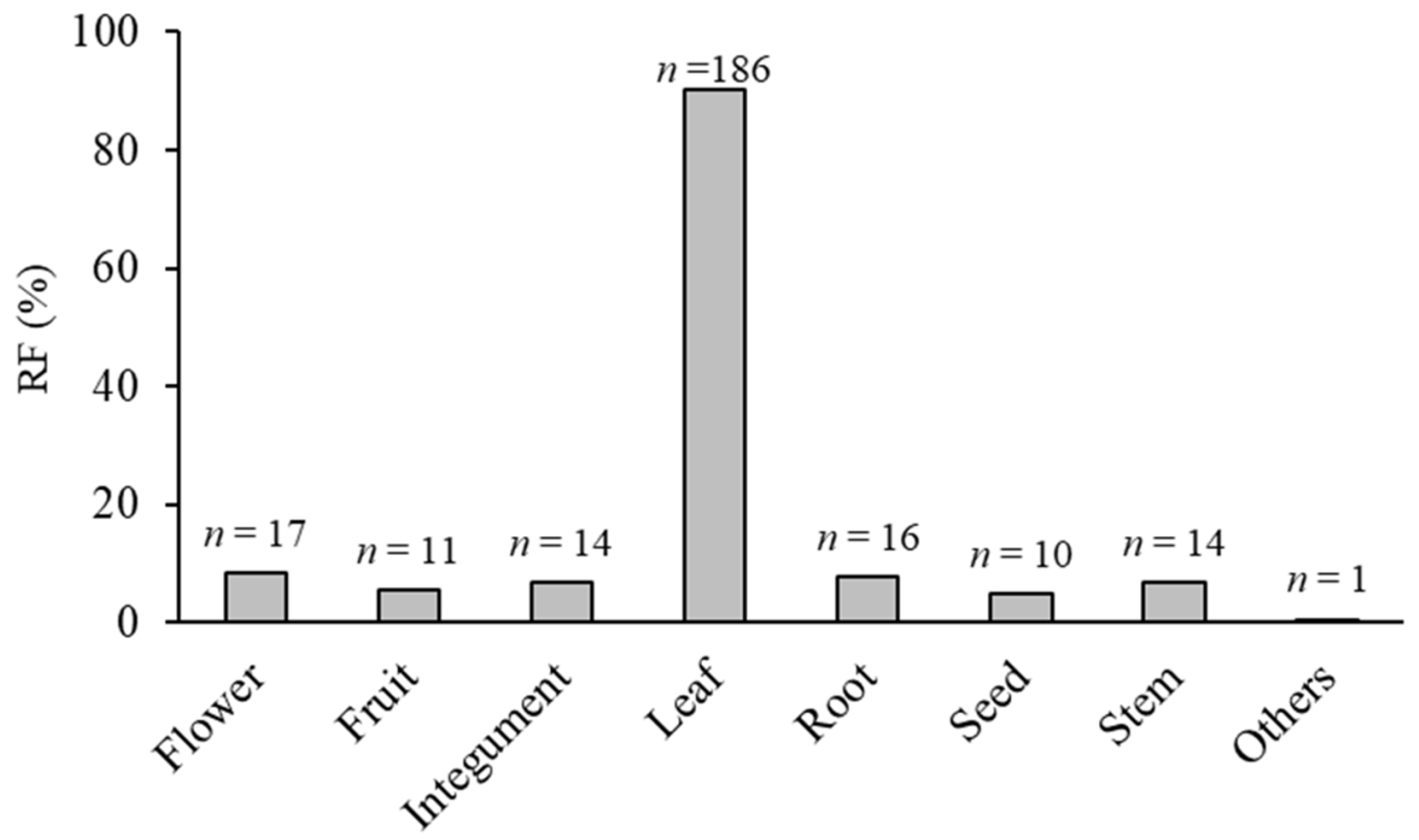

\section{Plant part}

FIGURE 3 - Main parts of the plants used in the medicinal preparations cited by the students and their associated community at a public school in Vila Velha (Brazil). $n$ represents the number of answers for each category considering 206 people. 
TABLE I - Mean knowledge and attitude scores toward use of medicinal plants of students and their associated community at a public school in Vila Velha (Brazil)

\begin{tabular}{lll}
\hline \multirow{2}{*}{ Subject } & \multicolumn{2}{c}{${\text { Respondents' } \text { answers }^{\mathbf{1}}}$} \\
\cline { 2 - 3 } & Yes & No \\
\hline Use of medicinal plants & 80.58 & 19.42 \\
\hline Home cultivation & 34.95 & 65.05 \\
\hline Confidence in effectiveness & 90.78 & 9.22 \\
\hline Harvestingcare & 20.39 & 79.61 \\
\hline Concern about the amount used & 33.01 & 66.99 \\
\hline Toxicity & 30.10 & 69.90 \\
\hline Side effects & 15.05 & 84.95 \\
\hline Phytotherapy & 13.11 & 86.89 \\
\hline
\end{tabular}

${ }^{1} n=206$.

TABLE II - Prevalence ratio (PR) and relative frequency about use of medicinal plants of female and male students and their associated community at a public school in Vila Velha (Brazil)

\begin{tabular}{lccccc}
\hline \multirow{2}{*}{ Subject } & \multicolumn{3}{c}{ Female $^{1}$} & \multicolumn{3}{c}{ Male $^{2}$} & PR \\
\cline { 2 - 5 } & Yes & No & Yes & No & \\
\hline Use of medicinal plants & 80.17 & 19.83 & 81.18 & 18.82 & 0.99 \\
\hline Home cultivation & 29.75 & 70.25 & 42.35 & 57.65 & 0.70 \\
\hline Confidence in effectiveness & 93.39 & 6.61 & 87.06 & 12.94 & 1.07 \\
\hline Harvestingcare & 17.36 & 82.64 & 24.71 & 75.29 & 0.70 \\
\hline Concern about the amount used & 32.23 & 67.77 & 34.12 & 65.88 & 0.94 \\
\hline Toxicity & 33.88 & 66.12 & 24.71 & 75.29 & 1.37 \\
\hline Side effects & 10.74 & 89.26 & 21.18 & 78.82 & 0.51 \\
\hline Phytotherapy & 17.36 & 82.64 & 7.06 & 92.94 & 2.46 \\
\hline
\end{tabular}

${ }^{1} n=121 ;{ }^{2} n=85$. 
Although the data of the present research demonstrated a significant use of medicinal plants, only a small group of the interviewees had previously used phytotherapy (TABLE I). With the technological advances in allopathic medicine and the pharmaceutical industry in recent years, phytopharmaceutical agents have been positioned in second place and considered as medicine without scientific basis (Alves, Silva, 2003). The precarious use of phytotherapy faces a lack of popular knowledge for the effectiveness and disbelief of health professionals themselves, which discourages its use. For example, Silva and Marisco (2013) showed that in a study on pharmaceutical intervention for the prescription of herbal medicines, $22 \%$ of interviewed pharmacists did not believe in the pharmacological effect of this type of drug and, although there is demand for this type of medicine, they had difficulty in indicating them to patients. Thus, the main challenge in phytotherapy acceptance is the lack of knowledge and communication on the effects of herbal medicines mainly deriving from the medical professionals. Another challenge is that while the use of medicinal plants tends to have a very low cost, especially for those who grow them at home, the cost of such medicines, which are not always compatible with the financial possibilities of users, may either be as or more expensive than the traditional, industrialized ones. (Ibiapina et al., 2014).

It is worth mentioning that in the present survey the frequency of positive responses regarding the confidence in the use and effectiveness of medicinal plants among women over 45 years old was $100 \%$; reinforcing the idea that knowledge on popular tradition has great influence on the acceptance and effective use of this type of drug therapy. As stated by Lima et al. (2014), scientific literature indicated that information about this subject is essentially maintained by older people. Additionally, it has been commonly observed in literature that there is a higher percentage of women involved in the cultivation or preparation of medicinal herbs. Silva and Marisco (2013), for example, reported that the use of medicinal plants was more frequent for the female fraction of their interviewees, demonstrating that they have greater knowledge about plants and aspects related to the methods of preparation. A similar trend was observed by Valdivina-Pereira et al. (2009) evaluating the knowledge and use of medicinal plants by an urban community in the Brazilian municipality of Ponta-Porã in which their behavior reflected the paternalistic basis on which our society is built. As reported by Melis and
Vieira (2007), the higher prevalence observed among women was probably due to the culturally attributed role played by the female gender in domestic activities and family health, often being the main responsible for the home treatment of diseases. As reinforced by Pires et al., (2016), the historical conception of the social construction of gender reveals that the role of caring for the family and the need of knowledge related to medicinal plants is, most often, imposed over women.

In the present study, however, no association was found between the female sex and knowledge about medicinal plants when considering the total sampled population, as can be observed in TABLE II; evidenced by the balance in $\mathrm{PR}(\mathrm{PR} \cong 1)$ for most of the evaluated subjects. Thus, it is suggested that four main factors may act in either a combined or isolated way to facilitate the interruption of the intergenerational data chain to reduce the transmission of information and traditional values from older to younger women. The first factor related to the inefficient and precarious documentation of data (e.g. indications of use, forms of preparation, combinations of herbs), which hindered the transfer of robust and empirically proven procedures. The second related to the increasingly advanced age of the data holders, which often hindered communication with younger individuals due to the cultural gap (Carvalho et al., 2011). The third, by its turn, concerned the resistance or lack of interest of the new generations in the traditions and popular knowledge (Jima, Megersa, 2018); and the fourth, intimately associated to the third one, is related to the redefinition of the role of women in society, which is already perceived in preadolescence and adolescence, leading to a growing distance between the figure of the woman and the role of a housewife, thus being considered the primary responsible for the health and well-being of the family (Lima et al., 2009). It might be considered, however, that the lack of documentation and the difficulty of communication between generations also discouraged the transmission of this knowledge to young males.

Despite the transmission of information across generations being impaired over time, this still seems to be the main channel for prospection and absorption of information about medicinal plants. When questioned about the main source of obtaining information on therapeutic effects of medicinal plants, 54\% reported receiving information from parents or grandparents, $15 \%$ from television programs, $15 \%$ from informal conversations with people outside the family circle, 
and only $9 \%$ from internet, books or magazines. From these data, it is still possible to infer that, besides the precarious reading habit, there is a lack of interest in young people in relation to the subject since the active search for information by internet searches, books and magazines seems to be the least used source.

Medicinal plants in Brazil have high plant diversity and a low cost associated with therapeutics, which are both reasons that favor its use by the population in general, configuring an effective form of health care that complements or even replaces, in many cases, the drug treatment routinely used (Ibiapina et al., 2014). In many situations the modern health system is not able to meet the demand of the entire population and the belief in the healing power of plants leads people to enter into a consortium between the biomedical health system and the traditional one (Vandebroek et al., 2011).

Figure 4 compiles the main targets for the use of herbal medicines by the interviewed individuals. It was observed that $61.17 \%$ of the interviewees cited stomachache as the main frequent reason for the use of herbal medicines, while anxiety was cited as the second most frequent reason for use (49.03\%). These circumstances are directly related to the lifestyle of the current general population, which was characterized by frequent stress and poor eating habits. Nowadays, the impact of personal habits and lifestyle on people's health is undeniable. Despite that evidence shows genetics and environmental factors as important actors in health homeostasis, lifestyle still represents a differential factor for health establishment and wellbeing (Nahas et al., 2000). In accordance with those data, the plants most cited as used for medicinal preparations were 'Boldo' (54\%), mostly used for gastrointestinal discomfort, and 'Erva cidreira' (30\%) and 'Camomila' (12\%), both widely used as sedatives. The knowledge about these species seems to be widespread and highlighted by many interviewees in ethnobotanical researches, such as Zeni et al. (2017) and David et al. (2014). All plants mentioned by the school community used for medicinal preparations are compiled in TABLE III, with their respective indications of use.

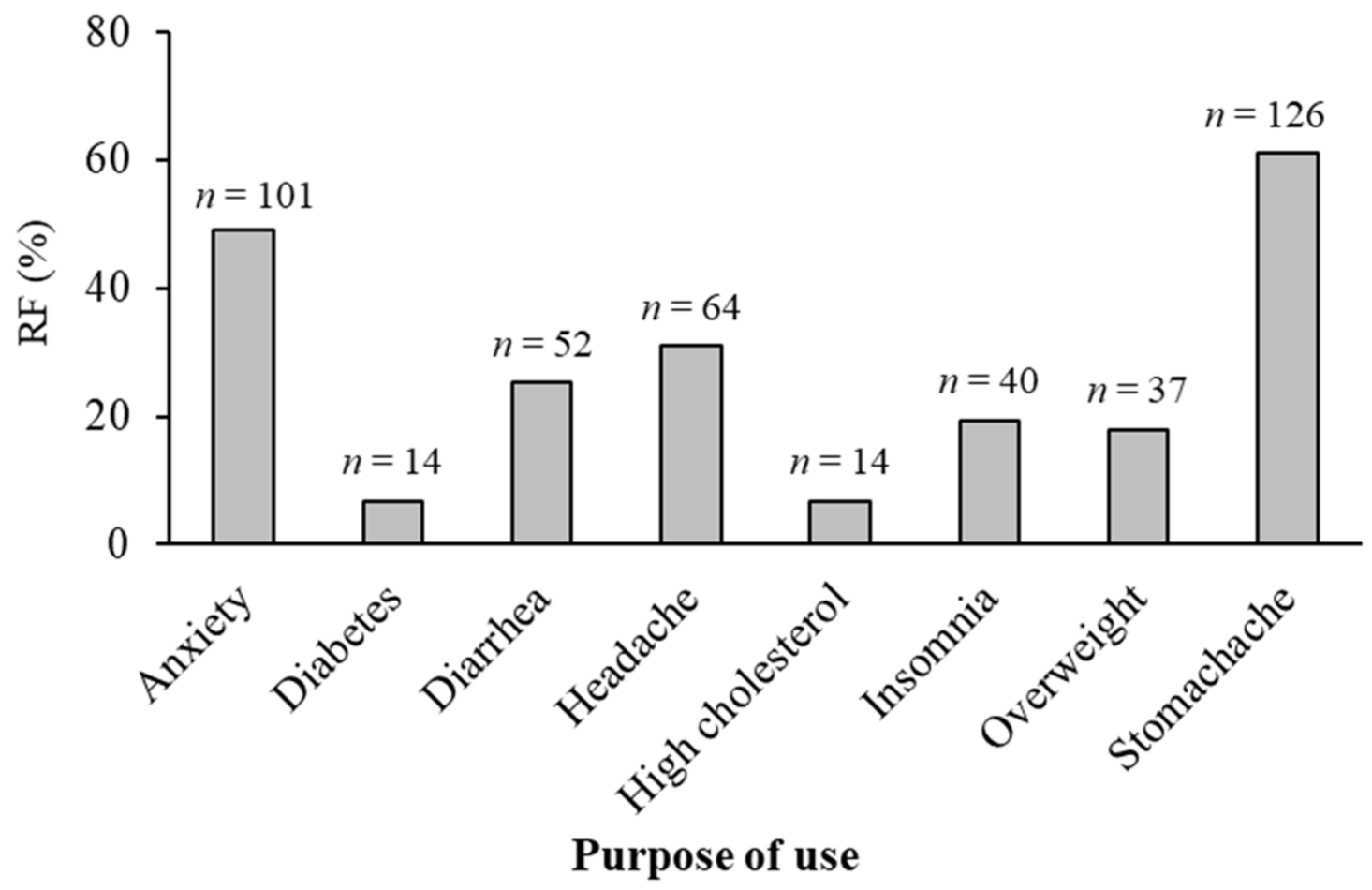

FIGURE 4 - Main diseases or conditions are most commonly used to treat with medicinal preparations were cited by the students and their associated community at a public school in Vila Velha (Brazil). $n$ represents the number of answers for each category considering 206 people. 
Perceptions and use of medicinal plants by an elementary and high school community in Vila Velha, Espírito Santo, Brazil

TABLE III - Correlation of the ethnospecies mentioned by the respondents (vernacular name) with the corresponding families, species, plant part and indications of use cataloged in The Plant List (2013). Bold letters indicate the most cited plant species

\begin{tabular}{lccc}
\hline Plant family & $\begin{array}{c}\text { Vernacular } \\
\text { name }\end{array}$ & Scientific name & Plant part
\end{tabular}$\quad$ Indications of use

\begin{tabular}{lcccc}
\hline Amaranthaceae & $\begin{array}{c}\text { Erva-de- } \\
\text { santa-maria }\end{array}$ & $\begin{array}{c}\text { Dysphania ambrosioides (L.) } \\
\text { Mosyakin \& Clemants }\end{array}$ & $\begin{array}{c}\text { Cramps, bruises, stomach problems, } \\
\text { flu, cough, asthma, bronchitis, lung } \\
\text { infection, laryngitis, tuberculosis, } \\
\text { angina, poor circulation, varicose veins, } \\
\text { hemorrhoids, intestinal parasites in } \\
\text { general, mycoses, allergy to insects. }\end{array}$ \\
Apiaceae & Erva-doce & Pimpinella anisum L. & Seed & $\begin{array}{c}\text { Dyspepsia, flatulence, abdominal } \\
\text { pain and arthritis. }\end{array}$ \\
Aquifoliaceae & Ilex paraguariensis & A. St. Hil. & Leaf & $\begin{array}{c}\text { Overweight, hypercholesterolemia, } \\
\text { diabetes, hunger, sleepiness, poor } \\
\text { circulation, dyspepsia, cardiovascular } \\
\text { and respiratory diseases. }\end{array}$ \\
\hline
\end{tabular}

\begin{tabular}{ccc} 
Asteraceae Camomila $\quad$ Matricaria chamomilla L. Flower $\begin{array}{c}\text { spasms, menstrual disorders, insomnia, } \\
\text { irritability, ulcers, intestinal disorders, } \\
\text { rheumatism and hemorrhoids }\end{array}$ \\
\hline
\end{tabular}

\begin{tabular}{|c|c|c|c|c|}
\hline Celastraceae & $\begin{array}{l}\text { Espinheira- } \\
\text { santa }\end{array}$ & $\begin{array}{l}\text { Maytenus ilicifolia Mart. } \\
\text { Ex Reissek }\end{array}$ & Leaf & $\begin{array}{c}\text { Gastric and intestinal ulcers, gastritis, } \\
\text { dyspepsia, constipation, and liver problems. }\end{array}$ \\
\hline
\end{tabular}

\begin{tabular}{lcccc}
\hline Equisetaceae & Cavalinha & Equisetum giganteumL. & Hole plant & Edema, swelling and overweight \\
Lamiaceae & $\begin{array}{c}\text { Boldo- } \\
\text { brasileiro }\end{array}$ & $\begin{array}{c}\text { Plectranthus barbatus } \\
\text { Andrews }\end{array}$ & Leaf & $\begin{array}{c}\text { Headache, cold sweats, malaise, } \\
\text { gastrointestinal discomfort and dyspepsia. }\end{array}$ \\
Lamiaceae & Erva cidreira & Melissa officinalis L. & Leaf & $\begin{array}{c}\text { Disorders of the intestinal tract, } \\
\text { nervous system, liver and bile, } \\
\text { insomnia and dyspepsia. }\end{array}$
\end{tabular}

Lamiaceae Cordão-de-fradeLeonotis nepetifolia (L.) R.Br. Hole plant

Lauraceae Canela Cinnamomum sp. Integument

Asthma, cough, intestinal cramps, apathy, edema and swelling, rheumatism, gastric ulcers and uterine bleeding.

Flatulence, bloating sensation, gastric ulcers and dyspepsia.

Dysentery, pharyngitis, gingivitis, vaginal yeast infections, throat inflammation,

Lythraceae Romã Punica granatum L. $\quad$ Fruit
laryngitis, bleeding gums, thrush, worms, hoarseness, mouth conditions, throat and gums, canker sore.


TABLE III - Correlation of the ethnospecies mentioned by the respondents (vernacular name) with the corresponding families, species, plant part and indications of use cataloged in The Plant List (2013). Bold letters indicate the most cited plant species

\begin{tabular}{|c|c|c|c|c|}
\hline Plant family & $\begin{array}{l}\text { Vernacular } \\
\text { name }\end{array}$ & Scientific name ${ }^{1}$ & Plant part & Indications of use \\
\hline
\end{tabular}

\begin{tabular}{|c|c|c|c|c|}
\hline Malvaceae & Algodão & Gossypium herbaceum L. & Leaf & $\begin{array}{l}\text { Control of menstrual bleeding, impaired } \\
\text { lactation, nausea, diarrhea, gastrointestinal } \\
\text { discomfort, fever and headache. }\end{array}$ \\
\hline Malvaceae & Hibisco & Hibiscus sabdariffa L. & Flower & $\begin{array}{l}\text { Swelling, edema, hypertension, } \\
\text { inflammation, constipation and } \\
\text { irritation of the respiratory tract. }\end{array}$ \\
\hline Moraceae & Amora & Morus nigraL. & Fruit & Kidney diseases \\
\hline Myrtaceae & Goiaba & Psidium guajavaL. & Flower & $\begin{array}{l}\text { Bloating in the eyes, eye injuries } \\
\text { and conjunctivitis. }\end{array}$ \\
\hline Passifloraceae & Maracujá & Passiflora edulis Sims & $\begin{array}{l}\text { Fruit and } \\
\text { leaf }\end{array}$ & $\begin{array}{l}\text { Anxiety, depression, restlessness or } \\
\text { hyperactivity, insomnia, nervousness, } \\
\text { restlessness, high blood pressure, } \\
\text { headache caused by muscle stiffness, } \\
\text { nervous tension and muscle pain. }\end{array}$ \\
\hline Plantaginaceae & Tanchagem & Plantago major L. & Leaf & $\begin{array}{l}\text { Fever, swelling, inflammation and } \\
\text { irritation in the tissues, toothache, } \\
\text { hemorrhoids, sore throat, conjunctivitis. }\end{array}$ \\
\hline Poaceae & Capim limão & $\begin{array}{c}\text { Cymbopogon } \\
\text { citratus(DC) Stapf. }\end{array}$ & Leaf & $\begin{array}{l}\text { Fever, excessive sweating, abdominal pain, } \\
\text { irritability, insomnia, depression, swelling, } \\
\text { nasal congestion, liver disease, intestinal } \\
\text { constipation, impaired peripheral circulation }\end{array}$ \\
\hline Zingiberaceae & Gengibre & Zingiber officinale Roscoe & Stem & $\begin{array}{l}\text { Diarrhea, nausea, vomiting, abdominal } \\
\text { pain, dyspepsia and reflux. }\end{array}$ \\
\hline
\end{tabular}

${ }^{1}$ Species commonly related to the vernacular name.

\section{CONCLUSION}

Based on described data, most individuals in the school community use medicinal plants, although many of them do not use them in a rational way and only few grow them at home. Knowledge about medicinal plants, their use and preparation seems to be essentially held by older people; and its transmission to younger generations occurs primarily through communication starting from the older individuals to the younger ones, thus characterizing the process of building this knowledge as based on interpersonal relationships. This situation raises the question of the interruption of such cultural transfer due both to the lack of documentation of data over time and to the lack of interest in the new generations of the subject. In this perspective, it is suggested that, through the inclusion of participatory methodologies to consider popular knowledge, the school can help minimize the distance between popular and scientific knowledge. Therefore, the results demonstrated that ethnopharmacological studies at the school community may contribute both to the conservation of plant biodiversity and to the 
maintenance and dissemination of cultural knowledge about the undoubtedly benefits of medicinal plants.

\section{ACKNOWLEDGMENTS}

The following institutions and organizations are acknowledged for financial, material, and/or logistic support: Programa de Pos-graduação em Ciências Farmacêuticas from Vila Velha University; Fundação de Amparo à Pesquisa e Inovação do Espírito Santo (FAPES); State School of Elementary and High School 'Agenor de Souza Lé'.

\section{REFERENCES}

Albertasse, P D, Thomaz, L D, Andrade, M A. Plantas medicinais e seus usos na comunidade da Barra do Jucu, Vila Velha, ES. Rev Bras Plantas Med. 2010;12(3):250-60.

Albuquerque U P, Andrade L H C, Silva A C O. Use of plant resources in a seasonal dry forest (northeastern Brasil). Acta Bot Bras. 2005;19(1):27-38.

Albuquerque U P, Lucena R F P, Alencar N L. Métodos e técnicas para a coleta de dados etnobotânicos. In: Albuquerque U P, Lucena R F P, Cunha L V F C C (orgs.). Métodos e técnicas na pesquisa etnobotânica. 2nd ed. Recife: NUPEEA; 2008. p. 48-50.

Almeida E R. As plantas medicinais brasileiras. São Paulo: Hemus; 1993. 341 p.

Alves AR, Silva MJP. O uso da fitoterapia no cuidado de crianças com até cinco anos em área central e periférica da cidade de São Paulo. Rev Esc Enferm USP. 2003;37(4):85-91.

Cappelleti Nagai S, Ferreira Alves A, Justin A, Cazissi da Silva C, Godoy Abreu L. Plantas medicinais: projeto de educação ecológica desenvolvido por acadêmicos de enfermagem. Saúde Col. 2010;7(42):173-78.

Carvalho O C, Pinto G A, Araújo F C, Teixeira F D. Estudo sobre a importância do resgate do saber popular sobre plantas medicinais e sua transmissão em escolas públicas de São João Del Rei - MG. In: VIII Encontro Nacional de Pesquisa em Educação em Ciências. 2011, Campinas. Campinas: Associação Brasileira de Pesquisa em Educação em Ciências, 2011. 7p.

David M, Mamede J S S, Dias G S, Pasa M C. Uso de plantas medicinais em comunidade escolar de Várzea Grande, mato Grosso, Brazil. Biodiversidade. 2014;13(1):38-50.
Eisenberg D M, Kessler R C, Foster C, Norlock F E, Calkins D R, Delbanco T L. Unconventional medicine in the United States. New Engl J Med. 1993;328(4):246-52.

Freire C J, Barbosa L R S, Costa J G, Santos R G A, Santos A F. Phytotherapy in pediatrics: the production of knowledge and practices in Primary Care. Rev Bras Enferm. 2018;71(1):637645 .

Fuck S B, Athanázio J C, Lima C B, Ming L C. Plantas medicinais utilizadas na medicina popular por residentes da área urbana de Bandeirantes, PR, Brasil. Semina: Ciênc. Agrár. 2005;26(3):291-96.

Harvey A L, Edrada-Ebel R, Quinn R J. The re-emergence of natural products for drug discovery in the genomics era. Nat Rev Drug Discov. 2015;14(2):111-129.

Heisler E V, Badke M R, Andrade A, Rodrigues M G S. Saber popular sobre a utilização da planta Anredera cordifolia (folha gorda). Texto Contexto Enferm. 2012;21(4):937-44.

Ibiapina W V, Leitão B P, Batista M M, Pinto D S. Inserção da fitoterapia na atenção primária aos usuários do SUS. Rev Ciênc Saúde Nova Esperança. 2014;2(1):58-68.

Jima T T, Megersa M. Ethnobotanical study of medicinal plants used to treat human diseases in Berbere District, Bale Zone of Oromia Regional State, South East Ethiopia. J Evid Based Complementary Altern Med. 2018;2018(1):1-16.

Jolly S, Vittinghoff E, Chattopadhyay A, Bibbins-Domingo $\mathrm{K}$. Higher cardiovascular disease prevalence and mortality among younger blacks compared to whites. Am J Med. 2010;123(9):812-18.

Kovalski M L, Obara A T. O estudo da etnobotânica das plantas medicinais na escola. Ciênc educ (Bauru). 2013;19(4):911-27.

Lima A R A, Heck R M, Vasconcelos M K P, Barbieri $\mathrm{R}$ L. Actions of women farmers in family care: use of medicinal plants in southern Brazil. Texto Contexto Enferm. 2014;23(2):365-72.

Lima C B, Bellettini N M T, Silva A S, Cheirubm A P. Janani J K, Vieira M A V, Amador T S. Uso de Plantas Medicinais pela População da Zona Urbana de Bandeirantes - PR. Rev Bras Biocienc. 2007;5(1):600-02.

Lima L S, Beltrame G R, Martins J F, Jaeger F P. A adolescência e o ser mulher na contemporaneidade: a visão das adolescentes de baixa renda. Disc. Scientia. Série: Ciências Humanas. 2009;10(1):89-103. 
Madikizela B, Ndhlala A R, Finnie J F, Van Staden J. Ethnopharmacological study of plants from Pondo land used against diarrhoea. J Ethnopharmacol. 2012;141(1):61-71.

Maroyi A. An ethnobotanical survey of medicinal plants used by the people in Nhema communal area, Zimbabwe. J Ethnopharmacol. 2011;136(2):347-54.

Melis J V, Vieira A O S. O conhecimento de plantas medicinais em uma comunidade rural de Londrina, Paraná. Rev Bras Biocienc. 2007;5(1):411-13.

Messias M C T B, Menegatto M F, Prado A C C, Santos B R, Guimarães M F M. Uso popular de plantas medicinais e perfil socioeconômico dos usuários: um estudo em área urbana em Ouro Preto, MG, Brasil. Rev Bras Plantas Med. 2015;17(1):76104.

Murray-Smith C, Brummitt N A, Oliveira-Filho A T, Bachman S, Moat J, Lughadha E M, Lucas E J. Plant diversity hotspots in the Atlantic Coastal Forests of Brazil. Conserv Biol. 2009;23(1):151-63.

Nahas, M V, Barros M GV, Francalacci V. O pentáculo do bem estar: base conceitual para a avaliação do estilo de vida em indivíduos ou grupos. Rev Bras Ativ Fis Saúde. 2000;2(5):48-59.

Kumar B M, Nair P K P. The enigma of tropical homegardens. Agroforest Syst. 2004;12(61):135-52.

Napagoda M T, Sundarapperuma T, Fonseka D, Amarasiri S, Gunaratna P. An Ethnobotanical Study of the Medicinal Plants Used as Anti-Inflammatory Remedies in Gampaha District, Western Province, Sri Lanka. Scientifica. 2018;2018(1):1-8.

Orhan I E. Pharmacognosy: science of natural products in drug discovery. BioImpacts. 2014;4(3):109-10.

Phillips O, Gentry A H. The useful plants of Tambopata, Peru: II. Additional hypothesis testing in quantitative ethnobotany. Econ Bot. 1993; 47 (1): 33-43.

Pires I F B, Sousa A A, Lima C A, Costa J D, Feitosa M H A, Costa S M. Plantas medicinais: cultivo e transmissão de conhecimento em comunidade cadastrada na Estratégia Saúde da Família. Rev Bras Pesq Saúde. 2016; 18(4): 37-45.
Rodrigues R, Carlini E A. Ritual use of plants with possible action on the central nervous system by the Krahô Indians, Brazil. Phytother Res. 2005;19(2):129-35.

Samuelsson G, Bohlin L. Drugs of natural origin: A treatise of pharmacognosy. $7^{\text {th }}$ ed. Stockholm: Swedish Pharmaceutical Press; 2017. 808 p.

Santomé J T. As culturas negadas e silenciadas no currículo. In: Silva T T (Org.). Alienígenas na sala de aula: uma introdução aos estudos culturais em educação. 6th Ed. Petrópolis: Vozes; 1995. p.159-177.

Silva T S S, Marisco G. Conhecimento etnobotânico dos alunos de uma escola pública no município de Vitória da Conquista/BA sobre plantas medicinais. Biofar. 2013;9(3):112.

Siqueira, M P S. Industrialização e empobrecimento urbano: o caso da Grande Vitória. 1ª edição.Vitória: EDUFES, 2001.

Siviero A, Delunardo T A, Haverroth M, Oliveira L C, Mendonça A M S. Plantas medicinais em quintais urbanos de Rio Branco, Acre. Rev Bras Plantas Med. 2012;14(4):598-610.

Valdivina Pereira Z, Mussury R, Barbosa de Almeida A, Sangalli A. Plantas medicinais utilizadas pela comunidade de Ponta Porã, Mato Grosso do Sul. Acta Sci Biol Sci. 2009,31(3):293-299.

Vandebroek I, Reyes-García V, Albuquerque U P, Bussmann R W, Pieroni A. Local knowledge: Who cares? J Ethnobiol Ethnomed. 2011;7(35):1-7.

Zeni A L B, Parisotto A V, Mattos G, Santa Helena E T. Utilização de plantas medicinais como remédio caseiro na Atenção Primária em Blumenau, Santa Catarina, Brasil. Ciên Saúde Colet. 2017;22(8):2703-12.

Received for publication on $01^{\text {st }}$ March 2019 Accepted for publication on $05^{\text {th }}$ August 2019 